\title{
Islam and Politics in the North Caucasus
}

\author{
ANNA ZELKINA
}

Until very recently the Soviet Union was synonymous with Russia in the eyes of most western observers. Even experienced sovietologists tended to examine the Soviet Union principally from a Russian perspective. This was probably inevitable, since the Soviet authorities were anxious to spread the idea of the existence of a 'new entity' - namely 'the Soviet people' - with a single undifferentiated sovietised Russian culture. Various nations 'went underground' in order to preserve their cultural, linguistic and religious identities. The peoples of the western republics of the USSR tried, to some extent successfully, to get their message out to the free world in the hope of gaining support. The Muslim nations took fewer initiatives since they distrusted Christendom and did not regard the western countries as their allies and supporters. Maintaining contact with either the West or the Muslim world was in any case always extremely difficult and could incur heavy penalties. Even the dissidents coming out of the Soviet Union were mostly unable or unwilling to bring news of the Islamic republics; many of them regarded these areas as the 'diki vostok' (backward Orient), the colonial hinterland of Russia, inhabited by 'bezgramotnyye dikari' (illiterate barbarians). The Soviet Muslims in their turn saw such people as alien westerners and Russian colonisers, and did not trust them. The Muslim republics of the USSR thus remained remarkably unknown to the outside world.

This was not always so. Only a century ago events in Central Asia and the Caspian area were closely followed by western observers. Politicians anxiously noted the Russian advances into the area and adventurers travelled extensively in these 'exotic lands'. All this was brought to an end in the 1920s when the bolsheviks established their rule in those areas and made them virtually inaccessible to foreign travellers. Despite the continuing efforts of a few western orientalists who in the teeth of all difficulties continued their research in those areas, the Islamic republics of the USSR became terra incognita.

Since the sudden disintegration of the Soviet Union in autumn 1991, a number of newly independent states have appeared on the political map, and little is generally known about their inner structures. The West was suddenly reminded of the existence of the Muslim states in the former USSR, but what is not fully appreciated is that these states were never fully integrated by the Russian and Soviet authorities. They preserved structures of society based on Muslim law (shari'a) and local tradition (adat) that persisted with remarkable vitality throughout the whole period of their colonisation.

The violence and instability which have become characteristic of the Muslim areas of the former Soviet Union make it important to understand the nature of those societies and the driving forces within them. The reemergence, or rather the legalisation, of Islam and Muslim institutions made it seem as though we were witnessing the rise of religious fundamentalism in these areas. However, it would be wrong to assume, 
as many western pundits do, that Islam is the main and united driving force of this independence movement. I propose in this paper to show that the situation is much more complex, with economic, national and tribal ambitions being equally important.

One of the most complex situations is in the North Caucasus, where more than $\mathbf{5 0}$ different nationalities are represented in a population of only four million. ${ }^{1}$ Before the Russian colonisation in the mid-nineteenth century, the whole area had never been conquered or united under the rule of one people or one dynasty and the numerous ethnic groups had preserved their cultural and linguistic identities. These societies, however, had many similarities, and joint struggle against foreign invaders contributed to the development of a common self-identity. This group identity vis-à-vis nonMuslim, Russian domination was largely based on Muslim religious unity.

Recent political turmoil has once again brought the situation in the North Caucasus to the notice of the western world, primarily through the 'Chechen crisis' in November 1991, which resulted in the creation of an independent Chechen Republic (formerly a part of the Chechen-Ingush Autonomous Region within the Russian Federation). Rather than taking each republic in turn, I would like to focus on this small mountainous republic, which represents a microcosm of the problems common to the whole region.

The Chechen Republic, situated in the eastern part of the North Caucasus, borders on North Ossetia in the west, Georgia in the south, Dagestan in the east and the Russian Stavropol' area in the north. According to the 1989 census, the population numbered 1,200,000 Chechens and Ingushes. The absolute majority of the population are Sunni Muslims; strong influence is wielded by the Naqshbandi and Qadyri Sufi brotherhoods.

Unlike Dagestanis, Circassians and some other North Caucasian peoples who by the end of the eighteenth century had formed small feudal states, the Vainakhs (as the Chechens and Ingushes call themselves) were organised in so-called self-governing societies administered by councils of elders (mehk qel). They spoke two dialects of a single Ibero-Caucasian Nah language, a division that would subsequently form the basis of the two national groups, Chechens and Ingushes.

It was not until the seventeenth century that Islam started to make some progress among the Vainakhs, who were still holding to pagan beliefs somewhat influenced by Georgian Christianity. Muslim missionaries from neighbouring Dagestan had limited success in spreading their message, however. Customary law remained for centuries far stronger than the shari'a. Besides, constant campaigns against Turkish and Persian invaders, who had long-standing aspirations to subjugate the area, did not contribute to the development of pan-Muslim sentiments. The situation changed radically, however, when Russia overtook its political rivals in the region and so became for the local population the principal enemy.

The first Russian attempts at colonisation of the North Caucasus were made during the reign of Peter the Great (1682-1725), but it was not until the second half of the eighteenth century that the systematic colonisation of the area started. The Russian annexation of the Crimean peninsula in 1780 made its advance in the Caucasus virtually inevitable, and the long-lasting Russian desire to turn the Caspian Sea into the inner sea of the Empire seemed close to fulfilment. However, it took the Russians more than half a century of persistent and bloody struggle to complete the conquest even of the North Caucasus.

The resistance movement to Russian advance was organised under the auspices of the Muslim Sufi brotherhoods. Sufism started as an individual search for the Way towards God in the early centuries of Islam, but by the twelfth and thirteenth centuries 
it had swelled into a popular mass movement of organised brotherhoods of adepts. Members of such brotherhoods were grouped around a master and bound by compulsory rules which regimented every aspect of their lives. The North Caucasus was among the last Muslim territories to which Sufism made its way in the late eighteenth and early nineteenth centuries, but once established there it soon came to dominate both social and political life. The first brotherhood to be introduced into the North Caucasus was the Naqshbandi order. ${ }^{2}$ It seems that the first to preach it in the late eighteenth century was a native Chechen from the aul (village) of Aldy, sheikh Mansur Ushaurma. ${ }^{3}$ However, it was not until the mid-1820s that the Naqshbandi order was established there by its Khalidiya branch. ${ }^{4}$

The beginning of the nineteenth century in the North Caucasus was marked by political and social turmoil. The traditional way of life was disrupted by the Russian invasion and numerous peoples were losing their independence. The rule of various local leaders who had chosen to hold on to their titles in return for their allegiance to the Russians appeared to the common people increasingly unjust and illegitimate. In addition, Russian anti-Islamic policies threatened people with the loss of their identity. In this atmosphere the ideas preached by the Naqshbandiya-Khalidiya about the supremacy of the shari'a in both private and public life and the obligation of the Muslim ruler to maintain that priority and preserve the umma (Muslim community) found fertile ground in the North Caucasus. For the first time the various North Caucasian peoples were provided with a sense of group identity based on Muslim religious unity and were able to produce the leadership for a durable resistance movement. The role played by the Naqshbandi order in the North Caucasus was not a unique phenomenon within Sufism. Throughout its history the order displayed a singular ability to superimpose a larger religious identity upon ethnic, tribal or clan loyalties, to promote Islam among non-Muslims and to strengthen it among Muslims. More than once it had proved capable of organising Muslims for resistance movements or for a jihad (holy war).

It seems that although the Naqshbandis in the North Caucasus accepted the necessity of jihad they saw their principal task as establishing the supremacy of the shari'a. ${ }^{5}$ Only under pressure from widespread anti-Russian sentiments among the Caucasian people did the emphasis in their activity gradually shift towards organising a massive resistance movement. The task of establishing the supremacy of the shari'a in every sphere of life was not overshadowed, however. Shamil, the foremost Naqshbandi leader, combined leadership in the resistance movement with the organisation in 1834 of the various North Caucasian societies into an imamate (theocratic state), the Imamate of Shamil. Shamil worked hard to replace the old customs with the laws of the shari'a in every sphere of life. The existence of this state was brought to an end in 1859 when Shamil surrendered to the Russian authorities and was exiled. Although he did not succeed completely in uprooting traditional law it was due to him that Islam finally triumphed in Vainakh society.

While in some parts of the Empire the tsars combined the policy of converting Muslims to Orthodox Christianity with that of the promotion of Muslim religious organisations (as a means of control), ${ }^{6}$ in the North Caucasus they pursued from the very start a systematic campaign against the Sufi brotherhood. Most of the leaders were killed or died in Russian jails, and ordinary adepts were forced out beyond the borders of the Russian Empire to settle in Ottoman territory. At the same time 'loyal' ulama were brought into the North Caucasus from the other Muslim areas of the Empire to denounce the Sufi adepts as 'sectarians' and fanatics. These officially sponsored ulama enjoyed very limited support among the local population, however, 
and the Naqshbandi order, though considerably weakened, continued to flourish. What is more, a new order - the Qadiriya order - was introduced into the area. Although the Kunta Haji, who was the first to promote the new order, preached abstention from politics and concentration on self-purification, he very soon followed the example of the Naqshbandiya. Numerous pockets of military resistance held out until 1864, and in 1877 a new wave of rebellions organised by both the Naqshbandi and Qadiriya orders swept over Chechnya and Dagestan. These rebellions were also crushed by the Russians; but despite defeat and severe repression the Naqshbandi and Qadiri brotherhoods maintained their positions and by the end of the nineteenth century had practically absorbed official Islam. They were incorporated into the clan structure of the Chechen and Ingush societies and became an important part of national self-identity.

The outbreak of the Russian Revolution in 1917 meant the sudden destruction of the tsarist regime and the start of a struggle for power. The peoples of the North Caucasus tried to take advantage of the situation and once again united their efforts in a vigorous attempt to gain independence. The First Congress of the North Caucasus formed a Provisional Government of the North Caucasian Free State (SeveroKavkazskoye Svobodnoye Gosudarstvo) and in May 1918 declared the establishment of the North Caucasian Republic. The only country to recognise it was Turkey. Neither the old Russian army nor the new bolshevik government, despite all its propaganda about the right of colonised peoples to self-determination, recognised the declaration of independence. After consolidating their position in the centre, the bolsheviks were able in 1919 to launch a new campaign to recolonise the Muslim areas of the old Russian Empire. After the independent North Caucasian Republic collapsed the Naqshbandi order once again mobilised the population in Chechnya for a jihad against the new 'godless' regime. Uzun Haji, a Chechen Naqshbandi adept, announced the creation of the North Caucasian Emirate, to be governed by Muslim law. After the death of Uzun Haji, the emirate was occupied by the bolsheviks in 1920 . The military resistance inspired by the Naqshbandi brotherhood lasted for another five years, however, and was finally crushed only in 1925 .

This revolt had an important impact on the history of the entire Muslim world, for it must be remembered that in the 1920 s the bolsheviks were seriously considering the possibility of an armed intervention in the Muslim Middle East. One Red Army division had already landed in Enzeli to help the Jengelis of Mirza Kuchuk Khan in their march to Tehran; pro-Soviet elements were angling for political power in Khorasan and Tabriz. One may speculate that the persistent revolts against the bolsheviks in the Northern Caucasus and Turkestan influenced the adoption of a more cautious policy by the Soviet state in Iran and Turkey.

At the time of the civil war the bolsheviks had already launched an unprecedented anti-religious campaign, involving the destruction of religious institutions, including mosques, madrasas and magatib (primary schools). In 1923 the separation of church and state was proclaimed. This was followed by a number of laws which prohibited the religious instruction of children, confiscated large religious endowments, took over the waqf lands and abolished religious courts. At the same time the Soviet authorities took to emphasising national differences in order to undermine Islam and diminish its influence in social and cultural affairs. According to Soviet classification a nation (natsiya) was defined as a group of people sharing a common history, language, cultural identity and political territorial organisation, comprising not fewer than 300,000 people; and nationality (narodnost') as membership of a smaller group based on tribal unity and common language. According to this classification the Chechens 
were a nation, while the Ingushes were a nationality. In 1922 a system of 'autonomous' national republics was established under Russian central state control. The republics were set up on the basis of ethnic and linguistic similarities, but part of the plan was to divide Muslims and forestall the development of common national or religious movements. Thus, separate Chechen and Ingush autonomous regions were created in 1922 and 1924 respectively. Later, however, these two regions were rearranged into the Chechen Soviet Socialist Autonomous Region, and in 1936, in order to pacify the rebels, promoted to the status of Autonomous Republic. This act did not bring the resistance to an end, however, and the uprisings continued, on and off, almost until the outbreak of the Second World War. In 1940 a major revolt broke out, led this time by a secular leader, Hasan Israilov. The aim of this resistance movement was as much national as religious. In June 1942, when the Germans were approaching the Caucasus from the south and south-east, Israilov issued an Appeal to the Chechen-Ingush People (Vozzvaniye $k$ Checheno-ingushskomu narodu) in which he stated that the Caucasians were expecting the Germans as guests but would welcome them only on condition that the latter completely recognised their independence. ${ }^{7}$ The Germans never reached the Chechen border and the rebellion of Hasan Israilov was crushed by the Red Army in 1944. On 23 February 1944, two years after Israilov's appeal, the Soviet authorities declared the Chechens and Ingushes 'nations of betrayers'. ${ }^{8}$ The whole of the Chechen and Ingush population was rounded up and deported en masse to Siberia and Kazakhstan. Very few managed to escape and take refuge in inaccessible mountain forests. There they continued to engage in guerrilla warfare, led by the Qadiri sheikh Batal-Khaji Belkhoroyev and his eleven sons. ${ }^{9}$

During the Second World War, and especially after the death of Stalin in 1953, the religious and cultural policies of the Soviet government were modified, although the main programme of political and cultural assimilation of the 'Muslim nations' into Soviet society remained unchanged. In 1943, in order to win Muslim support during the war, the Soviet authorities reestablished the Muftiyat (Directorate of Muslim Peoples) and the ulama were allowed to rebuild Islamic religious organisations under strict state control.

In 1957, four years after Stalin's death, the Chechen-Ingush Autonomous Republic within the Russian Federation was reorganised with new borders, ${ }^{10}$ and the Chechens and Ingushes were allowed to return to their homeland. On their return they found many of the villages burnt down and new owners living in the houses of those that remained. After the expulsion of the Chechens and Ingushes their lands had been resettled by Russians and Ukrainians who were fleeing from their own territories to escape devastation and hunger. The Chechens and Ingushes bought their houses back, but they were prevented from returning to the high mountain regions, which had always served as a stronghold for rebellions.

Traditionally farmers and warriors, the Chechens and Ingushes had turned during their exile in Kazakhstan into trading and entrepreneurial peoples, carrying on most of their business in Kazakhstan, Siberia and the Russian hinterland. In order to divert the energies of the Chechens and Ingushes away from politics, the Soviet authorities allowed them a certain degree of economic freedom - private enterprise and trade and privileges such as private ownership of land, houses and cattle. It was partly these freedoms and partly the highly organised structure of Chechen and Ingush society that allowed them to gain important positions in the Soviet black-market economy. In medieval times Sufi brotherhoods sometimes had links with trading guilds; now they again provided a necessary structure for such activity in twentieth-century communist Russia. The Sufi brotherhoods also proved to be efficient structures to ensure the 
survival of the community under extremely difficult circumstances. During the years of exile in Kazakhstan, where the Chechens and Ingushes lived in a Muslim but nevertheless hostile environment, Sufi identity had developed into feelings of national identity. The Sufi orders became extensively incorporated into the social structure, to the point where each individual had not only local, family and clan loyalties but also membership of a branch of one or another Sufi order.

The 'peaceful coexistence' established after 1957 between the Soviet authorities and the Chechen-Ingush peoples did not extend to the religious sphere. The Soviet authorities continued their antireligious propaganda. Sufi brotherhoods were once again subjected to systematic persecution. KGB agents were planted in almost every branch of the Sufi organisation and passed on information to central KGB headquarters. Many of the active Sufi adepts were hunted and arrested, this time not as 'reactionaries' or 'dissidents' but as 'criminals' (here the large-scale black-market activities of the Chechens often served as a good excuse). All the efforts of the Soviet authorities failed to suppress religion among the Chechens and Ingushes, however. Even those who were assimilated on a political level received a modern European education and accepted Soviet political and economic values maintained a separate identity at the family and ethnic level - an identity which incorporated religious elements, reinforced by language and ethnic consciousness. The Soviet legal system was of very limited application: family life as well as criminal law were regulated by the shari'a and adat. Most Chechens remained practising Muslims, and birth, death and marriage were marked in accordance with Islamic tradition and local customs. Muslim holidays were celebrated by all the people, while Soviet holidays, including the New Year, were hardly observed at all. Despite the fact that there were only seven working mosques in the whole of the republic, ${ }^{11}$ people continued to pray in their homes and gathered together for dhikr, a Sufi ritual of the remembrance of God, often involving singing and dancing. This ritual was held weekly in most villages, and was to some extent a substitute for common Friday prayers. It was usual that in a village of about 500 people there would be about $25-30$ active Sufi murids while the rest of the population consisted of non-active adepts of either the Naqshbandi or the Qadiri Sufi brotherhoods.

Perestroika was launched by Gorbachev in 1986, but did not affect the ChechenIngush Republic until much later. When it did, from 1989, it was not at first, as it was in other parts of the Soviet Union, in connection with the creation of new opposition parties, but with the legalisation of symbols of the Muslim faith. During 1990 Islam was almost completely legalised. In almost every village, mosques were reopened or newly built. Koranic and Arabic classes spread all over the republic. The restrictions on hajj, the Muslim pilgrimage to Mecca, were lifted. ${ }^{12}$ The brotherhoods were also legalised and played an active part in the reorganisation of the religious life of society. However, they were careful not to get directly involved in politics, and from the very beginning the emphasis was laid on the national rather than the Islamic orientation of the new political parties emerging in the Chechen-Ingush Republic, which were of a secular character. The two religious parties, the 'Islamic Revival Party' and 'Islamic Path', gained only a very limited following. The 'Islamic Revival Party', formed as a branch of the All-Union Islamic Revival Party, was never officially registered in the republic and from the very beginning 'Islamic Path' was designed to serve the political ambitions of its founder, a prosperous businessman called Bislan Gantemirov, rather than to implement his idea of the creation of a theocratic Muslim state in Chechnya.

The dominating organisation on the political scene in the Chechen Republic was the 'National Congress of the Chechen People'. It was formed in November 1990 by about 
1000 Chechen delegates who gathered in the capital city of Grozny from all parts of Chechnya as well as from other areas of the Soviet Union and abroad. ${ }^{13}$ The Congress elected an Executive Committee with General Dudayev as its chairman. Born in January 1944 in the village of Yalkhori in Chechnya, Dudayev was deported with his parents to Kazakhstan, where he was brought up. He belongs to the Artskhoi clan, on the border between the Chechens and Ingushes (half the Artskhoi give their nationality as Ingush and half as Chechen). Soon after his return to Chechnya in 1957, Dudayev left the republic to study at the Military Aviation school in Tambov, and then served in various parts of the Soviet Union. He was the first Chechen to reach the rank of Air Force general. Dudayev was commander of the strategic bomber division and head of the garrison in Estonia when he was invited back to Chechnya by the National Congress.

The Congress adopted a 'Declaraton of Independence of the Chechen Republic'. At that time, however, the majority of the population was less enthusiastic than the National Congress about the chances of securing immediate and complete independence from the Russian Federation. The breakup of the communist system opened up new possibilities for commercial and entrepreneurial activity involving direct relations with Russia. Most Chechens placed their hopes on Boris Yel'tsin, among whose closest supporters in Moscow was a native Chechen, Ruslan Khasbulatov.

When Yel'tsin came to power after the abortive coup of August 1991, he declared that all leaders who had supported the coup would be dismissed. Among others he had in mind the Soviet Chechen government. This declaration gave the green light to the National Congress, whose long-term aspiration was to replace the old communist leadership. On 15 September the National Congress seized power and a month later, on 27 October, held a general election. General Dudayev was elected the first president of the Chechen Republic. A few days later Dudayev declared the Chechen Republic an independent state.

Russia recognised neither the elections nor the declaration of independence. Yel'tsin made a clumsy attempt to restore a pro-Russian government in the Chechen-Ingush Republic. On 8 November he introduced a state of emergency in the republic and appointed a provisional administration with his representative Arsanov at its head. ${ }^{14}$ On Yel'tsin's orders a few troop units were sent to Grozny, but their number was so small that the Chechens succeeded in preventing them from leaving the airport. No military action was taken and there were no casualties. The Chechens also cut the railway line and the main highway between Baku (Azerbaidzhan) and Rostov (Russian Federation). President Dudayev appealed to all Muslims living in Moscow's to "turn Moscow into a disaster zone for the sake of our common freedom from $k u f r$ [blasphemy]'. This appeal started rumours of a nuclear threat from Chechnya. Two days later, on 10 November, the Russian Parliament countermanded Yel'tsin's order to use troops in the Chechen Republic. After the withdrawal of the Russian troops from Chechnya there were no further attempts at direct interference. The confrontation between the Russian authorities and Dudayev's government acquired more of an economic character. However, this incident had far-reaching consequences: it united the majority of formerly politically indifferent Chechens in their support for President Dudayev. About 70,000 volunteers from Chechnya and other Caucasian republics Dagestan, Kabardino-Balkaria, Georgia and Azerbaidzhan - arrived in Grozny to fight against the Russians. The Baltic states, Georgia, Dagestan, the Central Asian republics and some Middle Eastern countries ${ }^{16}$ expressed their political support for Dudayev. 
There was continuing opposition within the republic to Dudayev's government, backed by the Russian authorities and consisting of former local party and state employees, including employees of the KGB and MVD who had been dismissed by the new government. Their number was swollen by the support of their kinsmen, who joined them out of clan and territorial loyalty rather than political affiliation. At the same time, general instability and an increase in crime rates tended to drive more and more ordinary people into opposition. The increase in tension resulted in an attempted coup (31 March to 1 April 1992): the opposition seized the building of the local television station. The timing of the coup was inopportune. It was at the end of the Muslim fasting month of Ramadan, and according to Muslim law nobody should take arms. After two people had been killed, popular sympathy shifted in favour of Dudayev, and a few hours later the opposition withdrew without any further fighting.

The failure of the coup resulted in the consolidation of Dudayev's position and gave him time to implement his policies, his main aim being to win official recognition from the world community and to introduce social stability. So far no country has officially recognised the independence of the Chechen Republic. However, economic links have already been established with Ukraine, the Baltic states, Japan, Germany and Turkey. Turkey has advanced a loan for food supplies worth $\mathbf{4 0 0}$ million US dollars. Economic cooperation with Russia in the future is not excluded by Dudayev's government, which has more than once expressed a readiness to sign an agreement on the creation of a North Caucasian economic zone and stay within the rouble zone.

The new government seeks legitimisation in both secular and religious terms, for although it was secular nationalism which became the ideological basis for political independence, the Sufi orders had become an integral part of the social structure of Chechen society and the idea of national identity is interpreted in both ethnic and religious terms. After his election President Dudayev announced that he was going to build a state in accordance with Islam and swear an oath on the Koran. However, it seems that although Islam has been recognised as the state religion Dudayev is determined to keep it separate from politics. It is important for him to ensure the secular character of his state since he sees his own role as that of a mediator among the conflicting peoples of the Caucasus. One of his main ambitions is to create a federation of the mountain peoples of the Caucasus similar to the one that existed between 1917 and 1920. Dudayev's vision is of a confederation involving Christian as well as Muslim peoples, and he is therefore interested in combating every potentially disintegrative factor, including religion or ethnicity. Islam does not have a monopoly in the Chechen media: alongside Muslim ceremonies, Christian and Jewish services are now broadcast on local television. Dudayev has ambitiously proclaimed that the role of the Chechen Republic is a 'bridge between the Muslim East and the Christian West of the Caucasus'.

The Muslim dimension of the political and cultural heritage forms an important component, however, in the creation of the new postcommunist state and society. Secular symbols are meaningful to only a very limited section of the educated elite of the big cities, while the majority of the population remains faithful to traditional religious and clan values. As often happens at times of political and social turmoil, the Sufi brotherhoods have once again come to play a central role in public life. Unlike the situation in many Muslim countries, where the religious leaders have been equally opposed to colonial rule and to the influence of the secular elite, in Chechnya Dudayev and his government enjoy almost unquestioning support from the Sufi leaders. More than once the latter have held a large dhikr on the central square in Grozny to express their support, and more than once they have taken to the streets to prevent bloodshed. 
Indeed, it was through their mediation that the attempted coup of March 1992 ended practically without violence. This was a particularly important achievement in a society where the tradition of blood revenge is still very much alive.

The position of the brotherhoods in the present situation is, however, more complicated than it may appear at first sight. Rivalry between different clans could potentially inflame antagonism between the followers of the Qadiri brotherhood, who live mainly in the lowlands, and those of the Naqshbandi brotherhood, who live in the high mountain areas. Quite apart from this possibility, there is another area in which the potential of the brotherhoods has not yet been realised. A strong counterweight to Dudayev's government is represented by the Chechen Parliament. The struggle is mainly a question of who is to have real power in the newly created republic - the President and his circle or Parliament, chaired by Hussain Akhmadov. In this struggle both sides are appealing to the recently reestablished traditional institution of the mehk qel (council of elders), and seeking the support of Muslim and Sufi leaders. These traditional authorities of clan and religion still represent the main source of legitimation for the secular government. The importance of the cooperation of the Sufi orders with the government and their role in the transmission of governmental authority to the common people has been fully recognised. However, recent attempts by the council of elders to intervene more directly in the political life of the republic have perturbed both President and Parliament. Both would like to see the religious institutions subordinated to the state and confined to communal and religious affairs.

As far as Islam is concerned, it seems that its involvement in politics will depend on the degree to which any confrontation with Russia escalates, for throughout the centuries Islam has proved to be the force capable, more than any other, of unifying the Chechen people.

\section{Notes and References}

1 According to the 1989 census: Abkhazians 102,000; Kabardins 394,000; Karachai and Balqarand 245,000; Circassians 124,000; Ossetians 597,000; Chechens and Ingushes 1.2 million. With the exception of the Abkhazians and Ossetians the majority are Sunni Muslims.

2 Originating in Central Asia and named after sheikh Muhammad Baha al-Din Naqshband from Bukhara (1317-89), the Naqshbandi order became one of the most important and widespread Sufi brotherhoods in the Muslim world. It lays particular stress on strict adherence to the shari'a. It is a highly decentralised order with a distinct ability to adapt to changing social and political conditions.

${ }^{3}$ See Alexandre Bennigsen and S. E. Wimbush, Mystics and Commissars: Sufism in the Soviet Union (C. Hurst and Company, London, 1985), p. 18.

4 This branch was named after sheikh Diya al-Din al-Shahrazuri, who lived in Turkey from $1776(1780$ ?) to 1826 and made a profound impact on Naqshbandi theory and practice. On sheikh Khalid and the Khalidi suborder see, for example, A. H. Hourani, 'Sufism and modern Islam: Maulana Khalid and the Naqshbandi order', in The Emergence of the Modern Middle East (London, 1981), pp. 75-89; Butrus Abu Manneh, 'The NaqshbandiyaMujaddidiya in the Ottoman lands in early 19th century', Die Welt des Islams, vol. 22 (1982/4), pp. 1-36.

5 See M. Gammer, Shamil and the Muslim Resistance to the Russian Conquest of the NorthEastern Caucasus, $\mathrm{PhD}$ thesis, London School of Economics and Political Science, University of London, 1989, chapter 5.

6 This policy was adopted by Catherine the Great in 1773 in order to make Muslims loyal subjects of the Empire and put an end to numerous rebellions in the Islamic provinces. Thus decrees of 1782 and 1784 authorised the establishment of mosques, and Islamic spiritual 
administrations under the leadership of muftis were organised in Ufa in 1788 and in the Crimea in 1794.

${ }^{7}$ See A. Uralov (A. Avtorkhanov), Ubiistvo Checheno-ingushskogo naroda: narodo-ubiistvo $v$ SSSR (Moscow, 1991), pp. 59-60.

${ }^{8}$ As well as some other peoples of the North Caucasus: Balkars, Karachays, Kalmyks.

9 Ten of his sons were killed with their father. The one surviving son, Akhmad Belkhoroyev, was captured in 1947 and sentenced to ten years in prison. He was released in 1957 and returned to Chechnya, where he assumed the leadership of his brotherhood.

10 The eastern part of Vladikavkaz city and district, previously in Ingush territory, was included in the North Ossetian Autonomous Area. This move gave grounds for the territorial conflicts of today.

11 The mosques were in the following villages: Urus-Martan, Achkhoy-Martan, Shali, Ataghi and Churg-Yurt in Chechnya; and Nazran and Ayekazhevo in Ingushetya.

12 The hajj was not officially banned during Soviet rule, but a painful bureaucratic procedure meant that only Muslims of whom the Soviet authorities approved ideologically were allowed to go to Mecca.

13 After the Russian colonisation in 1860 more than one million Northern Caucasians left for Ottoman lands. The second wave of emigration followed the bolshevik revolution and the civil war. The majority of the North Caucasians at that time went to Turkey, Germany, France and Italy. Further émigrés in the late 1940s and early 1950s went by and large to the USA.

14 Arsanov comes from the same area as Khasbulatov himself. It seems that Ruslan Khasbulatov played a decisive role in advising Yel'tsin to interfere in Chechen affairs. Though living in Moscow, Khasbulatov retained a position in the structure of Chechen clan society. He was not at all pleased to see his political opponents gain power in the republic and hoped that with Russian help it would be possible to restore the position of his supporters - mainly members of the former leadership and businessmen trading in the Russian hinterland - and keep the Chechen Republic within the Russian Federation.

15 There are about 5000 Chechens permanently resident in Moscow and roughly the same number coming in every day for trade and business purposes.

16 The Jordanian MP and Minister of Parliamentary Affairs, Abd al-Baqi Jammi, an ethnic Chechen, was at that time in Grozny and it was largely due to him that the all-Caucasian Congress was held in Grozny in support of President Dudayev. 